\title{
WOODY NECROMASS STOCK IN MIXED OMBROPHILOUS FOREST USING DIFFERENT SAMPLING METHODS ${ }^{1}$
}

\author{
KARINA HENKEL PROCEKE DE DEUS ${ }^{2 *}$, AFONSO FIGUEIREDO FILHO ${ }^{3}$, ANDREA NOGUEIRA DIAS $^{3}$, IZABEL \\ PASSOS BONETE ${ }^{4}$
}

\begin{abstract}
The objective of this study was to quantify the necromass stock in a Mixed Ombrophilous Forest (MOF) fragment in the National Forest of Irati, State of Paraná, Brazil. Two sampling methods were tested: FA1, consisting of a fixed area (FA) approach with sample units measuring 2,500 $\mathrm{m}^{2}(50 \mathrm{~m} \times 50 \mathrm{~m})$; and FA2, consisting of fixed area sampling units measuring $500 \mathrm{~m}^{2}(10 \mathrm{~m} \times 50 \mathrm{~m})$ and line intercept sampling (LI) using $50 \mathrm{~m}$ lines. Data were collected on permanent sample plots installed in the area, consisting of 25 square blocks of 1 ha. Fallen dead wood pieces with a diameter $\geq 10 \mathrm{~cm}$ were used in the analysis. The dead wood was classified into three degrees of decomposition, and masses were calculated as the corresponding density at each class. The tested sampling methods were evaluated using coefficient of variation and relative sampling error, and the nonparametric Kruskal-Wallis test was used to compare the results between the methods. Volume size of fallen dead wood did not statistically differ between the methods, but variation in necromass volume was lower in the FA1 method, whereas the FA2 method had a smaller sampling error. Overall sampling error ranged from 23.4-27.92\%; lowering the sampling error to $15 \%$ would require a high sampling intensity (FA1: 42 area units [a.u.], FA2: 99 a.u., and LI: 236 a.u.). Total necromass weights

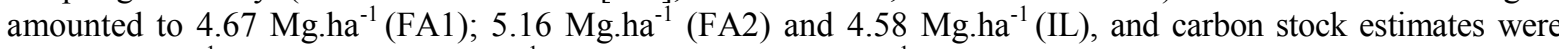
2.00 Mg.C.ha-1 (FA1); 2.20 Mg.C.ha ${ }^{-1}$ (FA2) and 1.96 Mg.C.ha $^{-1}$ (IL).
\end{abstract}

Keywords: Dead wood. Line intercept sampling. Fixed area sampling. Nonparametric statistics.

\section{ESTOQUE DE NECROMASSA LENHOSA EM FLORESTA OMBRÓFILA MISTA USANDO DIFERENTES MÉTODOS DE AMOSTRAGEM}

RESUMO - O estudo teve por objetivo quantificar o estoque de necromassa, em um fragmento de Floresta Ombrófila Mista, na Floresta Nacional de Irati, estado do Paraná. Dois métodos de amostragem foram testados, sendo área fixa (AF) com unidades amostrais de $2500 \mathrm{~m}^{2}(50 \mathrm{~m} \times 50 \mathrm{~m})$-AF1; área fixa com unidades amostrais de $500 \mathrm{~m}^{2}(10 \mathrm{~m} \times 50 \mathrm{~m})$ - AF2 e método de amostragem por Linha Interceptadora (LI), com linhas de $50 \mathrm{~m}$. Os dados foram coletados em parcelas permanentes instaladas na área, constituídas por 25 blocos quadrados de 1 ha. Foram medidas peças de madeira morta caída com diâmetro $\geq 10 \mathrm{~cm}$. A madeira morta foi classificada em três graus de decomposição e a massa foi calculada conforme a densidade correspondente a cada classe. Os métodos de amostragem testados foram avaliados por meio do Coefíciente de Variação e do Erro de Amostragem Relativo. Para comparações dos resultados entre os métodos utilizou-se o teste não paramétrico de Kruskal-Wallis. Os volumes para madeira morta caída não diferiram estatisticamente entre os métodos, porém o método AF1 teve menor variação do volume de necromassa e o método AF2 apresentou menor erro de amostragem. O erro amostral variou de $23,4 \%$ a 27,92 \% entre os métodos. Para atingir um erro de amostragem de 15\% seria necessária uma elevada intensidade amostral (AF1: 42 unidades de área [u.a.], AF2: 99 u.a., e LI: 236 u.a.). O peso total de necromassa foi de 4,67 Mg.ha ${ }^{-1}$ (AF1); 5,16 Mg.ha' (AF2), e 4,58 ${\mathrm{Mg} . h a^{-1} \text { (LI) e o estoque de carbono foi de 2,00 Mg.C.ha- }{ }^{-1} \text { (AF1); 2,20 Mg.C.ha }}^{-1}$ (AF2), e 1,96 Mg.C.ha ${ }^{-1}$ (LI).

Palavras-chave: Madeira morta. Linha Interceptadora. Amostragem em área fixa. Teste não paramétrico.

${ }^{3}$ Department of Forestry Engineering, Universidade Estadual do Centro-Oeste do Estado do Paraná, Irati, PR, Brazil; afigfilho@gmail.com - ORCID: 0000-0001-9965-7851, anogueiradias@hotmail.com - ORCID: 0000-0002-7721-1856.

${ }^{4}$ Department of Mathematics, Universidade Estadual do Centro-Oeste do Estado do Paraná, Irati, PR, Brazil; ipbonete@unicentro.br ORCID: 0000-0001-5479-5599.
} 


\section{INTRODUCTION}

Forests play an important role in mitigating climate change (SANQUETTA; DALLA CORTE; MAAS, 2013) by storing the atmospheric carbon with increasing biomass (BARBOSA et al., 2013). In addition, large carbon pools are also found in forest soils and necromass (FAO, 2013).

According to Harmon et al. (1986) and Ribeiro et al. (2012), necromass can be defined as any dead mass present in a forest resulting from woody residues (trunks of trees and branches in advanced states of decomposition), the minimum diameter of which can range from $2-10 \mathrm{~cm}$ for consideration in inventories, depending on the objective of the work (BARBOSA; SILVA; CAVALCANTE, 2009).

In mature forests, necromass represents about $5-25 \%$ of the total aboveground biomass (FAO, 2010). However, quantifications of this component for the purpose of assessing carbon stocks have rarely been incorporated into forest inventories (BROWN, 2002).

Maas (2015) stressed that forests not only act as sinks, but also as sources of carbon emissions, which can vary depending on changes in climate.

In this context, the expansion of scientific knowledge about the behavior of natural cycles involving carbon is a current necessity, given the considerable uncertainty about the magnitude and the regional distribution of forest carbon reservoirs, and our understanding of the dynamics of these reservoirs (STINSON et al., 2011; MAAS, 2015).

Research involving the dead wood forest is still scarce. In Brazil, most studies have been carried out in the Amazon Basin (KELLER et al., 2004; CHAO et al., 2009; CRUZ FILHO; SILVA, 2009; GONÇALVES SILVA et al., 2016), and in the Atlantic Forest (CARDOSO; VIBRANS; LINGNER, 2012; RIBEIRO et al., 2012; SILVA, 2013; SANQUETTA et al., 2014a; MAAS, 2015; OLIVEIRA, 2017).

The most commonly used sampling methods for estimating wood necromass volume are the line intercept and the fixed area plot. The line intercept method consists of arranging a predetermined size line on the forest floor and measuring the diameter of each piece of wood material that crosses the line (MAAS, 2015). Although it is a simple method, the line intercept requires considerable sampling intensity in order to attain acceptable levels of precision (SANQUETTA et al., 2014b). The advantages of the fixed area method, which normally involves significantly higher expenditures associated with the installation and maintenance of sample unit boundaries, include the practicality and simplicity of establishing such units in the field (SANQUETTA et al., 2014b).
Thick woody residues are difficult to quantify due to their irregular distribution. According to Miehs et al. (2010), this is particularly problematic in forest ecosystems in which these residues are relatively scarce, unequally distributed, and smaller than in other types of forest. In addition, there is no standardized method for sampling this type of material (TER-MIKAELIAN; COLOMBO; CHEN, 2008; MIEHS et al., 2010), making comparisons between published studies difficult. Thus, the present study sought to compare the efficacy of two sampling methods (fixed area and line intercept) in quantifying the necromass (dead wood on the soil) stock in a Mixed Ombrophilous Forest (MOF) fragment in the Irati National Forest, Paraná, Brazil.

\section{MATERIAL AND METHODS}

The research was carried out in the Irati National Forest (FLONA - Irati), which is located in the southern region of the state of Paraná, and encompasses a total area of 3,495 ha. This region is characterized by a $\mathrm{Cfb}$ climate (Köppen climate classification), with mean temperature varying from $13.8-21.4^{\circ} \mathrm{C}$ and mean precipitation ranging from 152-245.4 mm (ANTONELI; FRANCISQUINI, 2014). Data were collected from 25 permanent plots installed in an MOF fragment $(1,272.90$ ha). Blocks were 1 ha $(100 \mathrm{~m} \times 100 \mathrm{~m})$ in size (Figure 1$)$, and divided into plots of 0.25 ha $(50 \mathrm{~m} \times 50 \mathrm{~m})$ and subdivided into 5 control ranges of 0.05 ha $(10 \mathrm{~m} \times 50 \mathrm{~m})$.

Two sampling methods were used: fixed area (FA) plots with two sizes (sample units), consisting of FA1 with 14 a.u. (area units) of $2,500 \mathrm{~m}^{2}$ of area $(50 \mathrm{~m} \times 50 \mathrm{~m})$ and FA2 with 42 a.u. of $500 \mathrm{~m}^{2}$ $(10 \mathrm{~m} \times 50 \mathrm{~m})$, which corresponded to 3.5 ha and 2.1 ha of sampling area, respectively; and a line intercept (LI) of $50 \mathrm{~m}$ in length, amounting to a total of $3,500 \mathrm{~m}$.

The sample units were distributed systematically and located in the P3 plot of each block (Figure 2). In the FA2 method, three bands were selected to compose the sample unit, with bands separated by $10 \mathrm{~m}$. For LI, 70 units were installed in lines placed within the P3 plot of 14 of the 25 blocks, and five lines spaced $10 \mathrm{~m}$ apart were established within each plot. Quantitative and qualitative data were obtained from all dead wood on the ground surface that was present in the sample units with a diameter $\geq 10 \mathrm{~cm}$ at the smallest tip.

Identical procedures were used for sampling and estimation of woody necromass volume in sample units FA1 and FA2. Every trunk, twig, or whole tree was measured and counted, and volume was calculated based on $1 \mathrm{~m}$ sections using the Smalian method. 


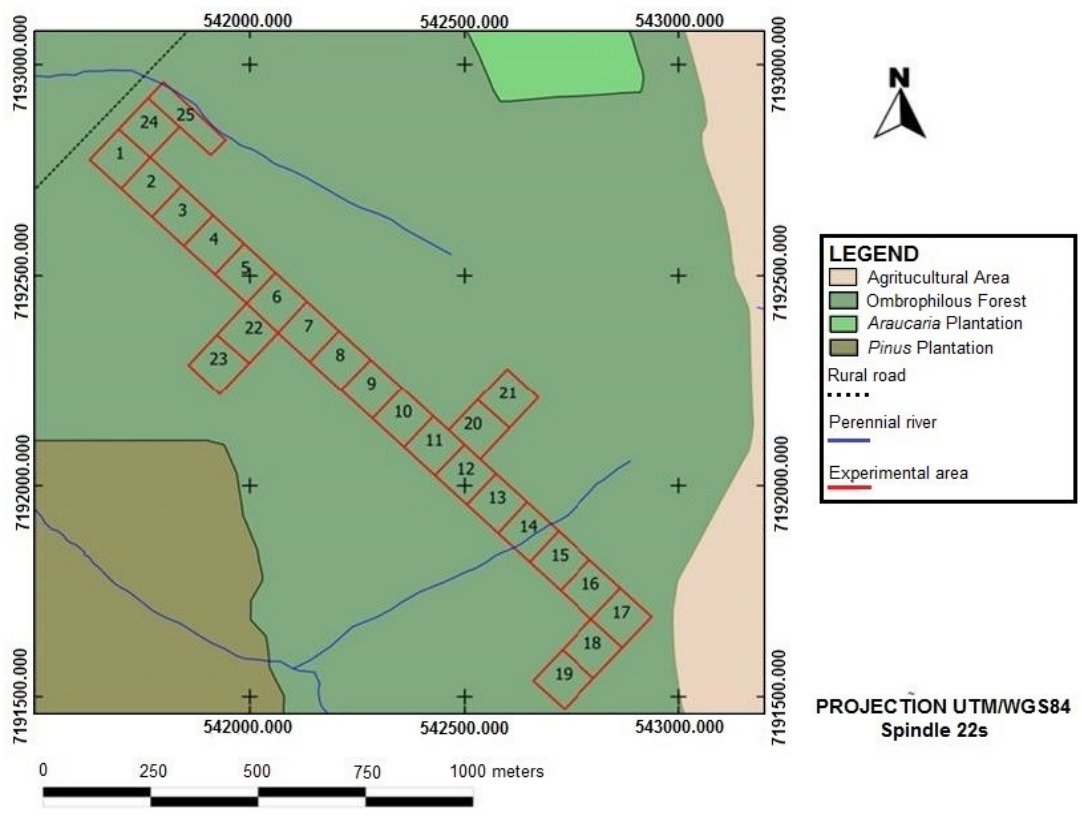

Figure 1. Permanent plots installed in the Irati National Forest.
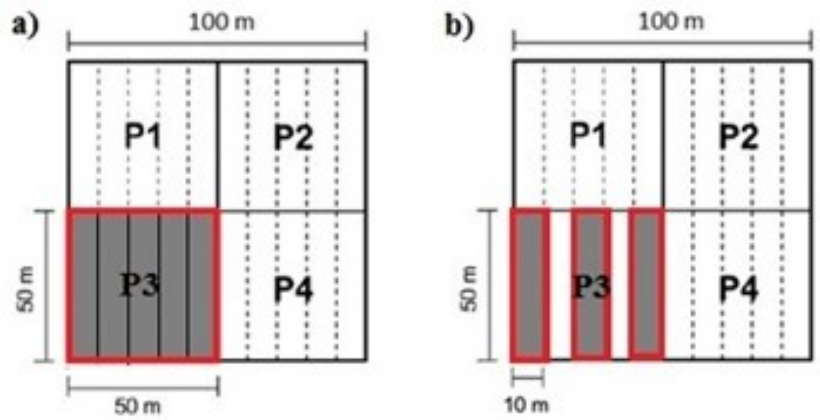

Source: Adapted from Rode (2008).

Figure 2. Schematic of a block. A) Plot $50 \mathrm{~m} \times 50 \mathrm{~m}$; b) plot $10 \mathrm{~m} \times 50 \mathrm{~m}$.

For dead wood measured via LI sampling, the diameters at the point of line intersection were measured for all woody material with a diameter $\geq 10$ $\mathrm{cm}$ that crossed the $50 \mathrm{~m}$ line. Criteria for measuring piece diameters were adapted from techniques recommended by Marshall, Davis and LeMay (2000), and the total volume per unit area was calculated using Van Wagner's (1968) equation (1):

$$
\mathrm{V}=\sum \mathrm{d}^{2} \cdot \frac{\pi^{2}}{8 . \mathrm{L}}
$$

where $V=$ volume; $D=$ the diameter of the pieces at the point of intersection $(\mathrm{cm})$; and $L=$ line length (m).

The pieces found amidst the sample area were classified according to the level of decomposition (tactile/visual) into three classes in accordance with the adapted methodology of the National Forest Inventory - SFN (SFB, 2014). These classes consisted of $\mathrm{C} 1$ : Initial decay - bark still intact, presence of branches, and texture of intact wood; $\mathrm{C} 2$ :
Intermediate decomposition - remnants of bark, without branches, and still firm wood; and C3: Advanced decomposition - without bark, without branches, and with wood in the stage of medium to advanced decomposition, crumbling appearance.

Statistical analysis was performed using samples chosen at random. To evaluate the accuracy of sampling, a 5\% probability of error was considered, with a sampling error of $15 \%$. As the data were not normally distributed and variances were non-homogeneous, comparison testing was performed using the non-parametric Kruskal-Wallis (KW) test, at $\mathrm{P}=0.05$.

To obtain necromass dry weight, different densities were used based on the degree of decay of the fallen dead wood. The wood densities we used were adapted from Maas (2015), in which $\mathrm{C} 1=0.46$ g. $\mathrm{cm}^{-3}, \mathrm{C} 2=0.35 \mathrm{~g} . \mathrm{cm}^{-3}$, and C3 $=0.24 \mathrm{~g} . \mathrm{cm}^{-3}$. The weight of fallen wood necromass was calculated using equation (2) (RÜGNITZ; CHACÓN; PORRO, 2009): 


$$
\mathrm{N}=\mathrm{Vol} \times \mathrm{D}_{\mathrm{b}}
$$

where $N=$ necromass $\left(\mathrm{Mg} \cdot \mathrm{ha}^{-1}\right)$ of fallen dead wood; Vol = volume $\left(\mathrm{m}^{3} \cdot \mathrm{ha}^{-1}\right)$ of dead wood; and $D b=$ basic density of dead wood $\left(\mathrm{g} \cdot \mathrm{cm}^{-3}\right)$.

To estimate the size of the carbon stock in the necromass, we used equation 3 :

$$
\Delta \mathrm{C}=\mathrm{N} * \mathrm{TC}
$$

where $\Delta C=$ amount of carbon in the necromass $\left(\mathrm{Mg} \mathrm{C} \mathrm{ha}{ }^{-1}\right) ; N=$ fallen dead wood necromass
$\left(\mathrm{Mg} \cdot \mathrm{ha}^{-1}\right) ; \mathrm{TC}=$ carbon content $\left(\mathrm{g} \cdot \mathrm{kg}^{-1}\right)$; and $\mathrm{C} 1=$ 437.7; $\mathrm{C} 2=429.6$, and $\mathrm{C} 3=424.6$ (MAAS, 2015).

\section{RESULTS AND DISCUSSION}

Estimated necromass volumes $\left(\mathrm{m}^{3} \cdot \mathrm{ha}^{-1}\right)$ based on the FA1, FA2, and LI methods, as well as the results from the Kruskal-Wallis analysis, are shown in Table 1.

Table 1. Comparison of the sampling methods.

\begin{tabular}{cccc}
\hline Method & Average volume & $X^{2}$ & P - value \\
\hline FA1 & 16.77 & $5.99^{\mathrm{ns}}$ & 0.0869 \\
FA2 & 18.89 & & \\
LI & 16.31 & & \\
\hline
\end{tabular}

FA: fixed area; LI: line intercept; ns: not significant.

As can be seen in Table 1, the FA2 sampling method generated higher estimates of dead wood volume than did the other methods, although the differences among the methods were not statistically significant $(\mathrm{P}=0.0869)$.

The calculated volumes were similar to estimates for an MOF in the state of Santa Catarina $\left(18.73 \mathrm{~m}^{3} \cdot \mathrm{ha}^{-1}\right.$, pieces with a diameter $\left.\geq 10 \mathrm{~cm}\right)$ made by Cardoso, Vibrans and Lingner (2012), but lower than those of Maas (2015) $\left(30.05 \mathrm{~m}^{3}\right.$.ha ${ }^{-1}$ for pieces with diameter $\geq 10 \mathrm{~cm}$ ) and Ribeiro et al. (2012) $\left(27.11 \mathrm{~m}^{3} \cdot \mathrm{ha}^{-1}\right.$, for pieces with diameter $\left.\geq 3 \mathrm{~cm}\right)$, both of whom focused on an MOF fragment in the state of Paraná. Oliveira (2017), who estimated the volume of woody residue on the ground (pieces with diameter $\geq 2.5 \mathrm{~cm}$ ) of an MOF, calculated an average volume of $20.04 \mathrm{~m}^{3} \cdot \mathrm{ha}^{-1}$. Analysis of the different methods for a $15 \%$ sampling error in the sample units FA1, FA2, and LI are summarized in Table 2.

Table 2. Coefficients of variation (CV), percentage errors (\% error), number of sample units measured (n), and number of sampling units ( $\mathrm{n}^{*}$ ) for $15 \%$ errors in necromass sampling using FA1, FA2, and LI methods in an MOF.

\begin{tabular}{lcccr}
\hline $\begin{array}{l}\text { Sampling } \\
\text { Method }\end{array}$ & CV\% & Error\% & $n$ & $n^{*}$ \\
\hline FA1 & 48.29 & 27.88 & 14 & 42 \\
FA2 & 75.09 & 23.40 & 42 & 99 \\
LI & 117.10 & 27.92 & 70 & 236 \\
\hline
\end{tabular}

$\mathrm{FA} 1=$ fixed Area $\left(2,500 \mathrm{~m}^{2}\right) ; \mathrm{FA} 2=$ fixed Area $\left(500 \mathrm{~m}^{2}\right) ; \mathrm{LI}=$ line intercept.

Coefficients of variation were high (Table 2), indicating that the woody stock was not homogeneously distributed within this forest, a pattern previously reported by Cardoso, Vibrans and Lingner (2012) and Oliveira (2017). In an inventory of a Santa Catarina forest, Cardoso, Vibrans and Lingner (2012) estimated the volume of woody residue with a diameter $>1 \mathrm{~cm}$ using 254 line transects $10 \mathrm{~m}$ in length and obtained a coefficient of variation of $149.06 \%$. Oliveira (2017), using 110 line transects also $10 \mathrm{~m}$ in length, calculated an even higher coefficient of variation $(249.92 \%)$ for diameters $>2.5 \mathrm{~cm}$.

Woldendorp et al. (2004), in an evaluation of the different sampling methods for estimating dead wood in an Australian forest system, used FAs with square sample units of $100 \mathrm{~m}^{2}, 400 \mathrm{~m}^{2}$, and 2,500 $\mathrm{m}^{2}$ and LI transects of different lengths $(10,20,40,60$, and $80 \mathrm{~m}$ ). They concluded that plots of fixed square area were more useful for measuring dead wood volumes in forests, and that variations $(\mathrm{CV})$ in necromass volume were high and tightly linked to sampling intensity. Moreover, the authors reported that smaller sample units resulted in higher CVs for both FA and LI methods. Similarly, Bate et al. (2004) compared the effectiveness of different sampling methods in estimating the characteristics of woody material in mixed conifer stands in Oregon and Montana, USA. These authors concluded that the best method is dependent on the objective of the forest inventory and local conditions, but indicated that the banded area sampling method was more 
accurate and efficient than LI approaches when estimating the volume and density of woody material with a diameter $\geq 15 \mathrm{~cm}$.

In contrast, Miehs et al. (2010), in a comparison of the efficacy of the LI and boundary area sampling methods in measuring woody material with diameter $\geq 5 \mathrm{~cm}$ in Eucalyptus forests, reported that variability was $20 \%$ lower for the LI method than for the boundary area approach, but they also noted that LIs shorter than $100 \mathrm{~m}$ were insufficient for generating accurate estimates of dead wood volume in these forest systems. The authors calculated CVs of $51.2 \%$ for a $450 \mathrm{~m}$ sample and $29.9 \%$ for a $700 \mathrm{~m}$ sample.

The sampling error (error \% in Table 2) for average volumes per hectare was higher than the desired value of $15 \%$. The lowest error $(23.40 \%)$ was obtained for the 42 a.u. in the FA2 sampling method followed by that of the 14 a.u. $(27.88 \%)$ in the FA1 and the 70 a.u. $(27.92 \%)$ for the LI. We determined that the number of sample units optimal for a $15 \%$ error would be 42 a.u. for FA1, 99 a.u. for FA2, and 236 a.u for LI. In a study carried out in an MOF near the city of São João do Triunfo, Paraná, Maas (2015) calculated an error of $58.43 \%$ when estimating the volume of dead wood using 60 a.u. of an LI $10 \mathrm{~m}$ in length.

Cardoso, Vibrans and Lingner (2012), in a study of necromass volume in an MOF in the states of Santa Catarina and Paraná, used a $15 \%$ error to estimate necromass volume of dead wood due to the heterogeneity of the analyzed variable, but instead obtained larger errors using the LI sampling method (16.36\% for material with a diameter below $20 \mathrm{~cm}$ and $25.76 \%$ for all material). Cardoso et al. (2013), who analyzed the ideal sampling intensities for different line lengths based on sampling errors of $10 \%$ and $15 \%$, found that optimal sampling intensity decreased with increasing line length.

Baker et al. (2007), while studying dead wood in forests in the Amazon Basin, compared stock estimates deriving from FA plots of 1 ha $(100 \mathrm{~m} \times 100 \mathrm{~m})$ and 0.1 ha $(20 \mathrm{~m} \times 50 \mathrm{~m})$, and an LI $100 \mathrm{~m}$ in length (a total of $400 \mathrm{~m}$ on each 1 ha plot) and determined that the volume estimated by the LI method $\left(62.26 \mathrm{~m}^{3} . \mathrm{ha}^{-1}\right)$ was higher than that estimated by the 1 ha FA approach $\left(33.47 \mathrm{~m}^{3} \cdot \mathrm{ha}^{-1}\right)$.

Total necromass mass was estimated to be 4.67 Mg.ha- ${ }^{-1}$ (FA1), 5.16 Mg.ha-1 (FA2), and 4.58 Mg.ha- ${ }^{-1}$ (LI). Silva (2013) estimated

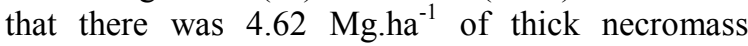
(diameter $\geq 10 \mathrm{~cm}$ ) in a Semideciduous Seasonal Forest outside of Rio de Janeiro based on the results of LI sampling. Although the physiognomy, climate, and region are different, their necromass estimate was similar to that of our study $\left(4.58 \mathrm{Mg}^{-h^{-1}}{ }^{-1}\right.$. In an inventory of a forest in Santa Catarina, Cardoso, Vibrans and Lingner (2012) estimated that there was 7.9 Mg.ha ${ }^{-1}$ of thick necromass (diameter $\geq 10 \mathrm{~cm}$ ) in an MOF, 4.6 Mg.ha- ${ }^{-1}$ in a Dense Ombrophilous Forest, and 4.3 Mg.ha ${ }^{-1}$ in a Deciduous Seasonal Forest; and Sanquetta et al. (2014a) estimated that the mass of dead wood material with a diameter $>7.5 \mathrm{~cm}$ amounted to $8.98 \mathrm{Mg}^{-h^{-1}}$ in a Semideciduous Seasonal Forest in Paraná.

Our estimates of carbon stocks (Figure 3) were lower than those reported by both Maas (2015) (4.24 Mg.C.ha ${ }^{-1}$ ) for an MOF fragment in São João do Triunfo, Paraná, and Sanquetta et al. (2014a) (7.65 Mg.C.ha ${ }^{-1}$ ) for a Semideciduous Seasonal Forest in Iguaçu National Park, PR.

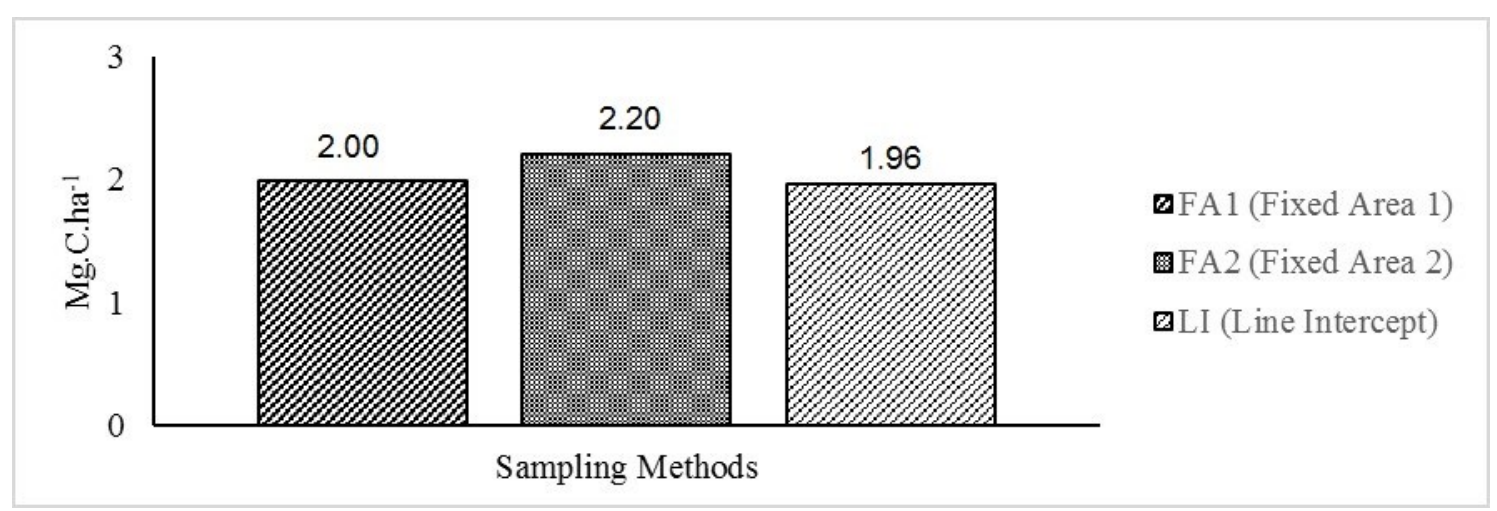

Figure 3. Estimates of carbon stocks of dead wood calculated from the sampling methods AF1, AF2, and LI in this MOF.

\section{CONCLUSIONS}

The methods evaluated in the present study presented a high degree of error than that desired, indicating the need for greater sampling intensity in order to improve accuracy. However, in terms of precision, the smallest sampling error was generated by the FA method with sample units of $500 \mathrm{~m}^{2}$, leading us to conclude that this method is the most effective approach for quantifying necromass volume in the study area. In addition, we recommend that higher sampling intensities be used in future research focusing on quantifying necromass volumes in this forest system. 


\section{REFERENCES}

ANTONELI, V.; FRANCISQUINI, V. M. Influência de alguns dados meteorológicos na produção de serapilheira na FLONA (Floresta Nacional) de Irati. Ambiência, Guarapuava, v. 10, Sup., p. 267-280, 2014.

BARBOSA, R. I.; SILVA, L. F. S. G.; CAVALCANTE, C. O. Protocolo necromassa: Estoque e produção de liteira grossa. 1. ed. Boa Vista, RR: PPBio Amâzonia. 2009. 24 p.

BARBOSA, R. R. N. et al. Produção e sequestro de carbono na atmosfera. Enciclopédia Biosfera, Goiânia, v. 9, n. 16, p. 1783-1798, 2013.

BAKER, T. R. et al. Low stocks of coarse woody debris in a southwest Amazonian forest. Oecologia, Berlin, v. 152, n. 3, p. 495-504, 2007.

BATE, L. J. et al. Performance of sampling methods to estimate $\log$ characteristics for wildlife. Forest Ecology and Management, Moscow, v. 199, n. 1, p. 83-102, 2004.

BROWN, S. Measuring carbon in forests: Current status and future challenges. Environmental Pollution, Essex, v. 116, n. 3, p. 363-372, 2002.

CARDOSO, D. J.; VIBRANS, A. C.; LINGNER, D. V. Inventário da necromassa florestal caída no chão nos remanescentes florestais de Santa Catarina. In: VIBRANS, A. C. et al. (Eds.). Inventário Florístico Florestal de Santa Catarina: Diversidade e Conservação de Remanescentes Florestais. Blumenau: Edifurb, 2012. v. 1, cap. 11, p. 217-227.

CARDOSO, D. J. et al. Determinação do comprimento ótimo de transectos para estimativa de necromassa florestal. Pesquisa Florestal Brasileira (PFB), Colombo, v. 33, n. 75, p. 317-325, 2013.

CHAO, K. J. et al. After trees die: Quantities and determinants of necromass across Amazonia. Biogeosciences Discussions, Munique, v. 6, n. 8, p. 1979-2006, 2009.

CRUZ FILHO, D.; SILVA, J. N. M. Avaliação da quantidade de resíduos lenhosos em floresta não explorada e explorada com técnicas de redução de impactos, utilizando amostragem por linha interceptadora, no Médio Mojú, Amazônia. Acta Amazônica, Manaus, v. 39, n. 3, p. 527-532, 2009

FOOD AND AGRICULTURE ORGANIZATION FAO. Global Forest Resources Assessment 2010. Rome: Food and Agriculture Organization of United Nations. Forestry Department, Relatório, 163 p., 2010.
FOOD AND AGRICULTURE ORGANIZATION FAO. Climate Change Guidelines for Forest Managers. FAO Forestry Paper n. 172. Rome: Food and Agriculture Organization of United Nations, Forestry Department, 2013.

GONÇALVES SILVA, L. F. S. et al. Production and stock of coarse woody debris across a hydro-edaphic gradient of oligotrophic forests in the northern Brazilian Amazon. Forest Ecology and Management, Victória, v. 364, n. 1, p. 1-9, 2016.

HARMON, M. E. et al. Ecology of coarse woody debris in temperate ecosystems. Advances in Ecological Research, Cambridge, v. 15, n. 1, p. 133 $302,1986$.

KELLER, M. et al. Coarse woody debris in undisturbed and logged forests in the eastern Brazilian Amazon. Global Change Biology, Hoboken, v. 10, n. 5, p. 784-795, 2004.

MAAS, G. C. B. Compartimentação do estoque de carbono em floresta ombrófila mista. 2015. $176 \mathrm{f}$. Tese (Doutorado em Engenharia Florestal: Área de Concentração em Manejo Florestal) - Universidade Federal do Paraná, Curitiba, 2015.

MARSHALL, P. L.; DAVIS, G.; LEMAY, V. M. Using Line Intersect Sampling for Coarse Woody Debris. Forest Research: Vancouver Forest Region, Canada, 2000, $37 \mathrm{p}$.

MIEHS, A. et al. Sampling downed coarse woody debris in fire-prone eucalypt woodlands. Forest Ecology and Management, Victória, v. 259, n. 3, p. 440-445, 2010

OLIVEIRA, K. A. Necromassa lenhosa e carbono em florestas no centro-sul, sudeste e centro ocidental paranaense. 2017. 68 f. Dissertação (Mestrado em Engenharia Florestal: Área de Concentração em Manejo Florestal) - Universidade Federal do Paraná, Curitiba, 2017.

RIBEIRO, A. et al. Proposta metodológica para realização de um inventário florestal de necromassa: um estudo de caso. Scientia Forestalis, Piracicaba, v. 40, n. 93 , p. 121-127, 2012.

RODE, R. Avaliação florística e estrutural de uma floresta ombrófila mista e de uma vegetação arbórea estabelecida sob um povoamento de Araucaria angustifolia de 60 anos. 2008. 159 f. Dissertação (Mestrado em Engenharia Florestal: Área de Concentração em Manejo Florestal) Universidade Federal do Paraná, Curitiba, 2008.

RÜGNITZ, M. T.; CHACÓN, M. L.; PORRO R. Guia para Determinação de Carbono em 
Pequenas Propriedades Rurais. 1. ed. Belém, PA: Centro Mundial Agroflorestal (ICRAF), 2009. 81 p.

SANQUETTA, C. R.; DALlA CORTE, A. P.; MAAS, G. C. B. El rol del bosque en el cambio climatico. Quebracho, Santiago del Estero, v. 19, n. 2, p. 84-96, 2013.

SANQUETTA, C. R. et al. Biomass and carbon in non-woody vegetation, dead wood and litter in Iguaçu National Park. Revista Floresta, Curitiba, v. 44, n. 2, p. 185-194, 2014a.

SANQUETTA, C. R. et al. Inventários Florestais: Planejamento e execução. 3 ed. Curitiba, PR: MultGraf Gráfica e Editora, 2014b, 270 p.

SERVIÇO FLORESTAL BRASILEIRO - SFB. Manual de Campo: Procedimentos para Coleta de Dados Biofísicos e Socioambientais. 1. ed. Brasília, DF: Serviço Florestal Brasileiro (SFB), 2014. 63 p.

SILVA, V. D. Respiração heterotrófica e estoques de necromassa em regiões de borda e interior em fragmentos de mata atlântica. 2013. 93 f. Dissertação (Mestrado em Ecologia e Recursos Naturais) - Universidade Estadual do Norte Fluminense Darcy Ribeiro, Campos dos Goytacazes, 2013.

STINSON, G. et al. An inventory-based analysis of Canada's managed forest carbon dynamics, 1990 to 2008. Global Change Biology, Hoboken, v. 17, n. 6, p. 2227-2244, 2011.

TER-MIKAELIAN, M. T.; COLOMBO, S. J.; CHEN, J. Amount of downed woody debris and its prediction using stand characteristics in boreal and mixed wood forests of Ontario, Canada. Canadian Journal of Forest Research, Ottawa, v. 38, n. 8, p. 2189-2197, 2008.

VAN WAGNER, C. E. The Line Intersect Method in Forest Fuel Sampling. Forest Science, Washington, DC, v. 14, n. 1, p. 20-26, 1968.

WOLDENDORP, G. et al. Analysis of sampling methods for coarse woody debris. Forest Ecology and Management, Camberra, v. 198, n. 1-3, p. 133148, 2004. 